\title{
Hormonal Interventions to Augment Fertility and its Effect on Blood Biochemical Profile in Crossbred Cows
}

\author{
Rajesh Kumar ${ }^{1 *}$, M.G. Butani ${ }^{2}$, F.S. Kavani ${ }^{3}$ and A.J. Dhami ${ }^{4}$ \\ ${ }^{1}$ Assistant Professor, Department of Veterinary Gynaecology \& Obstetrics, C.V. Sc. \& AH, ANDUAT, Aydhya, UP, India \\ ${ }^{2}$ Veterinary Officer, Amul Dairy, Anand, Gujarat, India \\ ${ }^{3}$ Professor \& Head, Department of Veterinary Gynaecology \& Obstetrics, C.V.Sc.\& A.H., AAU, Anand, Gujarat, India \\ ${ }^{4}$ Retd. Professor \& Head, Department of Veterinary Gynaecology \& Obstetrics, C.V.Sc.\& A.H., AAU, Anand, Gujarat, India
}

DOI: $10.36348 /$ sjls.2020.v05i09.005

| Received: 12.09.2020 | Accepted: 21.09.2020 | Published: 30.09 .2020

*Corresponding author: Dr. Rajesh Kumar

Abstract

A study was carried out on forty four problem breeder cows to evaluate the therapeutic efficacy of GnRH and PGF $2 \alpha$ for estrus induction response, time elapsed between treatment to estrus induction interval and conception rate and its effect on biochemical profile. Thirteen true anestrus cows were treated with GnRH (Inj. Receptal, $2.5 \mathrm{ml}$, IM, once), twenty three subestrus cows were treated with $\mathrm{PGF}_{2 \alpha}\left(\mathrm{PGF}_{2 \alpha}\right.$, Inj. Estrumet, $2 \mathrm{ml}$, IM, once) and eight animals kept as untreated anestrus control. The estrus induction response, treatment to estrus induction interval, overall conception rate and service per conception in $\mathrm{GnRH}$ treated, $\mathrm{PGF}_{2 \alpha}$ treated and positive control cows were 84.62\%, 28.27 \pm 6.46 days, $72.73 \%$, 3.13; $91.30 \%, 3.52 \pm 0.46$ days, $71.43 \%, 2.53$ and 50\%, 48.25 \pm 10.8 days, 50\%, 3.5 respectively. The plasma $\mathrm{P}_{4}$ level was significantly lower in all three groups as compared to other two periodic values (d-0 \& d-20-22 post AI) which were due to luteal demise. The mean serum total protein was significantly $(\mathrm{p}<0.05)$ lower in untreated anestrus $(8.57 \pm 0.36 \mathrm{~g} / \mathrm{dl})$ as compared to $\mathrm{GnRH}(9.75 \pm 0.28 \mathrm{~g} / \mathrm{dl})$ and $\mathrm{PGF}_{2 \alpha}(9.62 \pm 0.31 \mathrm{~g} / \mathrm{dl})$ treated cows. However, Total cholesterol was numerically lowest in control cows than those of treated contemporaries but did not differ significantly (168.22 \pm 17.22 ; $208.46 \pm 14.71 ; 163.84 \pm 10.64 \mathrm{mg} / \mathrm{dl}$; in $\mathrm{GnRH}, \mathrm{PGF}_{2 \alpha}$ and control group respectively, $\left.\mathrm{p}<0.05\right)$. The $\mathrm{Macro}(\mathrm{Ca}, \mathrm{P}$ and $\mathrm{Mg})$ and micro minerals ( $\mathrm{Zn}, \mathrm{Fe}, \mathrm{Cu}, \mathrm{Co}$, and $\mathrm{Mn}$ ) did not differ significantly among different groups. In conclusion, anestrus and subestrus cows can be well managed with $\mathrm{GnRH}$ and $\mathrm{PGF}_{2 \alpha}$ therapy. The normal hormonal and biochemical milieu is essential for normal functioning of reproductive system.

Keywords: Anestrus cows, biochemical profile, hormone, minerals and subestrus cows.

Copyright @ 2020: This is an open-access article distributed under the terms of the Creative Commons Attribution license which permits unrestricted use, distribution, and reproduction in any medium for non-commercial use (NonCommercial, or CC-BY-NC) provided the original author and source are credited.

\section{INTRODUCTION}

Bovine anestrus syndrome is one of the most prevalent reproductive disorders of dairy cows [1,2] which results in significant economic loss due to prolonged calving interval, reduced calf crop, and shorter productive life [3]. To resume cyclicity threshold LH concentration is obligatory. Prolonged period of ovarian afunction and failure of ovulation is mainly due to suboptimal plasma LH concentration. The causes of anestrus are multifactorial in origin, and there is no single panacea to correct the clinical syndrome. In spite of nutritional management [4], it is primarily addressed by hormonal therapy [5]. Normal level of biochemical constituents are utmost important for normal reproductive function. Thus, the study was undertaken to assess the efficacy of hormonal treatment $\left(\mathrm{GnRH}\right.$ and $\mathrm{PGF}_{2 \alpha}$ ) for management of clinical syndrome of anestrus and its effect on blood biochemical profile.

\section{MATERIALS AND METHODS}

The study was carried out in the milk shed areas of Anand district, Gujarat. Anestrus cows were screened by twice trans-rectal palpation ten days apart and grouped as anestrus $(n=13)$, subestrus $(n=23)$ and positive control ( $\mathrm{n}=8$; untreated anestrus cows). All cows dewormed with Albendazole $3000 \mathrm{mg}$ and owners were supplied with $1 \mathrm{~kg}$ mineral mixture (Amul brand) for feeding to their cows @ 30g per day for one month. The anestrus cows were treated with single dose Buserelin acetate@10 10 g, intramuscularly (GnRH, Inj. Receptal, $2.5 \mathrm{ml}$, MSD) and subestrus cows were subjected with Cloprostenol@ $@ 500 \mu \mathrm{g}$, intramuscularly $\left(\mathrm{PGF}_{2 \alpha}\right.$, Inj. Estrumet, $\left.2 \mathrm{ml}, \mathrm{MSD}\right)$, respectively. The estrus induction response (EIR), treatment to estrus 
induction interval (TEI), cycle wise conception rate i.e. conception rate $(\mathrm{CR})$ at induced estrus (first service conception rate; FSCR), two subsequent natural estrus, and overall conception rate (OCR) were recorded. Estrus detection was done by visual observation and per rectal examination, if found in estrus, inseminated by village AI workers with frozen thawed semen following AM-PM rule. The animals were observed for return to estrus up to three cycles and returning animals were bred through AI. Pregnancy was confirmed by transrectal palpation 60 days post-AI.

Blood samples were collected on the day of treatment (d-0), day of induced estrus/AI and day 20-22 post-AI by jugular vein puncture in heparinized vacutainers. The plasma was separated out by centrifugation of samples on the spot and stored at $20^{\circ} \mathrm{C}$ with a drop of merthiolate $(0.1 \%)$ as preservative until analyzed. The plasma progesterone was estimated by employing standard RIA technique of Kubasic et al. [6]. The levels of protein, cholesterol, triglycerides and macro-minerals $(\mathrm{Ca}, \mathrm{P}, \mathrm{Mg}$ ) were estimated by using standard procedures and assay kits of Coral Clinical System, Goa on biochemistry analyzer. The generated data were analyzed statistically completely randomized design and Duncan's NMRT [7].

\section{RESULTS AND DISCUSSION}

\section{Estrus Induction response and Conception rate}

Estrus induction response, treatment to estrus induction interval, and conception rate were depicted in table. 1. The present findings suggest that ovulatory estrus can be induced in a month or so, with use of GnRH in apparently healthy anestrus cows. Variable EIR and CR with GnRH treatment in anestrus cows have been documented. Like current findings, Karmakar et al., [8] recorded similar EIR (85\%) using GnRH and vitamin A in true anestrus crossbred cows. Conversely, variable EIR and CR were reported by many previous researchers [3, 9, 10, 11, 12, 13, 14, 15].
Variation in EIR and CR might be due to variation in age, breed parity and nutritional status of animals. The present study clearly indicates that ovarian cyclicity with ovulatory estrus can be effectively induced in a month or so with GnRH in apparently healthy anestrus cows.

Like present observations in $\mathrm{PGF}_{2 \alpha-}$ treated subestrus cows, comparable findings was recorded by Gupta et al., [11] $(90 \%, 2.37 \pm 1.33$ days and 78\%; EIR, TEI and CR respectively) and El-Shahat and Badr [9] (87.5\% EIR, 53.7 $\pm 4.2 \mathrm{~h}$ TEI and $71.42 \% \mathrm{CR})$. Conversely, El-Desouky and Hussein [16] recorded variable response using standard dose versus over dose of $\mathrm{PGF}_{2 \alpha}(65 \%, 4.53 \pm 0.44$ days, $1.61 \pm 0.24$ and $84.60 \%$ with $500 \mu \mathrm{g}$ vs $85 \%, 2.47 \pm 0.10$ days, $1.41 \pm 0.17$ and $82.30 \%$ with $750 \mu \mathrm{g} ;$ EIR, TEI, SPC and CR respectively) in postpartum cows; Dailey et al., [17] reported lower EIR (41.6\%) where as Ratnaparkhi et al., [15] observed higher EIR and FSCR (100\% \& 40\%) in $\mathrm{PGF}_{2 \alpha}$ treated dairy cows.

The present findings clearly indicate that subestrus condition in cattle can be successfully treated with $\mathrm{PGF}_{2 \alpha}$. Whether prostaglandins (PGs) have direct effects on follicular growth prior to luteinizing hormone (LH) surge to initiate ovulation in livestock is unknown [18], but $\mathrm{PGF}_{2 \alpha}$ increases pituitary responsiveness to GnRH to release LH in the postpartum cows [19], however, PGs produced by the ovulatory follicle are indispensable for ovulation [20]. Furthermore, Pfeifer et al., [21] opined that $\mathrm{PGF}_{2 \alpha}$ can induce ovulation of dominant follicle by an independent mechanism of luteolysis and can be successfully used as an ovulation inducer in timed artificial insemination protocols for beef [22] and dairy cows [23]. The EIR, TEI and CR of treated cows was far more better as compared to untreated contemporaries, which suggest positive impact of $\mathrm{GnRH}$ and $\mathrm{PGF}_{2 \alpha}$ in management of anestrus and subestrus cases.

Table-1: Estrus induction response, estrus induction interval and conception rate of anestrus and subestrus cows to GnRH or PGF 2 treatment

\begin{tabular}{|c|c|c|c|c|c|c|c|c|}
\hline \multirow[t]{2}{*}{ Group } & \multirow[t]{2}{*}{ Therapy } & \multirow[t]{2}{*}{ EIR } & \multirow[t]{2}{*}{ TEI (days) } & \multicolumn{4}{|c|}{ Conception Rate (\%) } & \multirow[t]{2}{*}{ SPC } \\
\hline & & & & $1^{\text {st }} \mathrm{AI}$ & $2^{\text {nd }} A I$ & $3^{\text {rd }} \mathrm{AI}$ & OCR & \\
\hline $\begin{array}{l}\text { Anestrus } \\
(\mathrm{n}=13)\end{array}$ & $\begin{array}{l}\text { GnRH } \\
(10 \mu \mathrm{g})\end{array}$ & $\begin{array}{l}84.62 \% \\
(11 / 13)\end{array}$ & $28.27 \pm 6.46$ & $\begin{array}{l}18.18 \% \\
(2 / 11)\end{array}$ & $\begin{array}{l}44.44 \% \\
(4 / 9)\end{array}$ & $\begin{array}{l}40.00 \% \\
(2 / 5)\end{array}$ & $\begin{array}{l}72.73 \% \\
8 / 11\end{array}$ & $\begin{array}{l}3.13 \\
25 / 8\end{array}$ \\
\hline $\begin{array}{l}\text { Subestrus } \\
(\mathrm{n}=23)\end{array}$ & $\mathrm{PGF}_{2 \alpha}(500 \mu \mathrm{g})$ & $\begin{array}{l}91.30 \% \\
(21 / 23)\end{array}$ & $3.52 \pm 0.46$ & $\begin{array}{l}52.38 \% \\
(11 / 21)\end{array}$ & $\begin{array}{l}30.00 \% \\
(3 / 10)\end{array}$ & $\begin{array}{l}14.29 \% \\
(1 / 7)\end{array}$ & $\begin{array}{l}71.43 \% \\
15 / 21\end{array}$ & $\begin{array}{l}2.53 \\
(38 / 15)\end{array}$ \\
\hline $\begin{array}{l}\text { Anestrus control } \\
(\mathrm{n}=8)\end{array}$ & None & $\begin{array}{l}50 \% \\
(4 / 8)\end{array}$ & $48.25 \pm 10.80$ & $\begin{array}{l}25 \% \\
(1 / 4)\end{array}$ & $\begin{array}{l}33.33 \% \\
(1 / 3)\end{array}$ & None & $\begin{array}{l}50 \% \\
(2 / 4)\end{array}$ & 3.5 \\
\hline
\end{tabular}

EIR: Estrus induction response; TEI: Treatment to estrus induction interval; OCR: Overall conception rate; SPC: Service per conception

\section{Effect of Hormone Therapy on Plasma Progesterone}

The mean progesterone concentration $\left(\mathrm{P}_{4}\right.$ values) was depicted in table. 2. Significantly higher $\mathrm{P}_{4}$ was recorded at d-0 in GnRH and untreated control group which might be due to failure to diagnose presence of corpus luteum during trans-rectal ovarian palpation at commencement of experiment [24, 25]. Numerically highest $\mathrm{P}_{4}$ values was recorded at $\mathrm{d}-0$ in subestrus cows than GnRH and control groups, as former cows screened on the basis of presence of CL on the ovary. At d-20-22 post $\mathrm{AI}$, the $\mathrm{P}_{4}$ level was highest in $\mathrm{PGF}_{2 \alpha}$ group, it appears that exogenously 
administered $\mathrm{PGF}_{2 \alpha}$ strengthen the luteal activity of subsequently formed corpus luteum, as $\mathrm{PGF}_{2 \alpha}$ act at the level of hypothalamus and pituitary, enhance GnRH induced LH release [19]. Moreover, the highest conception rate at induced estrus in $\mathrm{PGF}_{2 \alpha}$ treated subestrus cows supported the view that luteal insufficiency might be a cause of lower conception rate at induced estrus in GnRH treated anestrus cows. The mean $\mathrm{P}_{4}$ value was higher in conceived cows as compared to non-conceived cows at d-20-22 post AI. Which suggest luteal inadequacy might be a cause of conception failure in such cows.

Table-2: Serum Progesterone profile at d-0, induced estrus and day 20-22 post AI in different categories of cows $($ Mean \pm SE)

\begin{tabular}{|l|l|l|l|l|l|}
\hline \multirow{2}{*}{ Therapy/status } & \multirow{2}{*}{ S } & \multicolumn{5}{|l|}{ Serum Progesterone $(\mathbf{n g} / \mathbf{m l})$} \\
\cline { 3 - 7 } & & At d-0 & At estrus/AI & At day-20-22 post AI & Overall or pooled \\
\hline GnRH/true anestrus & 13 & $1.94 \pm 0.40^{\mathrm{b}}$ & $0.51 \pm 0.10^{\mathrm{a}}$ & $4.62 \pm 2.01^{\mathrm{c}}$ & $2.36 \pm 0.75$ \\
\hline $\mathrm{PGF}_{2 \alpha} /$ subestrus & 23 & $3.99 \pm 0.58^{\mathrm{b}}$ & $0.54 \pm 0.05^{\mathrm{a}}$ & $6.09 \pm 1.42^{\mathrm{c}}$ & $3.54 \pm 0.65$ \\
\hline Control/untreated & 8 & $1.58 \pm 0.31^{\mathrm{b}}$ & $0.45 \pm 0.07^{\mathrm{a}}$ & $2.78 \pm 1.27^{\mathrm{c}}$ & $1.61 \pm 0.47$ \\
\hline Overall & 44 & $2.68 \pm 0.35^{\mathrm{b}}$ & $0.56 \pm 0.05^{\mathrm{a}}$ & $5.05 \pm 0.82^{\mathrm{c}}$ & $2.77 \pm 0.36$ \\
\hline Conceived & 25 & $3.02 \pm 0.62^{\mathrm{b}}$ & $0.52 \pm 0.08^{\mathrm{a}}$ & $7.71 \pm 1.15^{\mathrm{c}}$ & $3.75 \pm 0.66$ \\
\hline Non-conceived & 19 & $2.36 \pm 0.34^{\mathrm{b}}$ & $0.61 \pm 0.05^{\mathrm{a}}$ & $2.59 \pm 0.62^{\mathrm{b}}$ & $1.85 \pm 0.27$ \\
\hline
\end{tabular}

Means bearing different superscripts within row differ significantly $(\mathrm{p}<0.05)$

\section{Effect of Hormone Therapy on Plasma Biochemical Profile}

The overall mean total serum protein in untreated anestrus cows was significantly lower than GnRH and $\mathrm{PGF}_{2 \alpha}$ treated cows (table. 3). Lower total protein in anestrus cows was in accordance with many previous reports $[4,26,27,28,29,30,31]$. Furthermore, the protein level was lower in conceived cows as compared to nonconceived contemporaries and the findings are in agreement with Dhami et al. [32] who reported lower total protein in conceived than nonconceived cows $(9.30 \pm 0.19$ vs $10.80 \pm 0.20 \mathrm{mg} / \mathrm{dl})$ in ovsynch treated cows. Hypoproteinemia may cause deficiency of certain amino acids required for biosynthesis of gonadotrophins and other gonadal hormones, might cause reproductive endocrine anomaly leading to afunction of ovary [33]. Furthermore, Pandey et al., [34] opined that rise of plasma total protein might be associated with high level of estrogenic activity.

Table-3: Overall mean ( \pm SE) blood biochemical and macromineral status in different treatment groups and conceiving and non-conceiving cows

\begin{tabular}{|l|l|l|l|l|l|l|}
\hline Therapy/status & $\mathbf{n}$ & Total protein $\mathbf{( g / d l )}$ & $\begin{array}{l}\text { Cholesterol } \\
(\mathbf{m g} / \mathbf{d l})\end{array}$ & $\begin{array}{l}\text { Calcium } \\
(\mathbf{m g} / \mathbf{d l})\end{array}$ & $\begin{array}{l}\text { Phosphorus } \\
(\mathbf{m g} / \mathbf{d l})\end{array}$ & $\begin{array}{l}\text { Magnesium } \\
(\mathbf{m E q} / \mathbf{L})\end{array}$ \\
\hline GnRH/true anestrus & 13 & $9.75 \pm 0.28^{\mathrm{b}}$ & $168.22 \pm 17.22$ & $9.06 \pm 0.28$ & $8.61 \pm 0.27$ & $3.40 \pm 0.15$ \\
\hline $\mathrm{PGF}_{2 \alpha} /$ subestrus & 23 & $9.62 \pm 0.31^{\mathrm{b}}$ & $208.46 \pm 14.71$ & $10.68 \pm 0.26$ & $9.48 \pm 0.22$ & $3.70 \pm 0.14$ \\
\hline Control/untreated & 8 & $8.57 \pm 0.36^{\mathrm{a}}$ & $163.84 \pm 10.64$ & $9.39 \pm 0.12$ & $8.28 \pm 0.15$ & $3.09 \pm 0.14$ \\
\hline Overall & 44 & $9.57 \pm 0.18^{\mathrm{b}}$ & $187.89 \pm 8.56$ & $9.98 \pm 0.18$ & $8.72 \pm 0.15$ & $3.64 \pm 0.09$ \\
\hline Conceived & 25 & $9.41 \pm 0.27$ & $182.82 \pm 11.76$ & $10.04 \pm 0.29$ & $8.91 \pm 0.27$ & $3.84 \pm 0.11$ \\
\hline Non-conceived & 19 & $9.73 \pm 0.24$ & $192.59 \pm 12.47$ & $9.92 \pm 0.22$ & $8.55 \pm 0.17$ & $3.46 \pm 0.15$ \\
\hline
\end{tabular}

Means bearing different superscripts within column differ significantly $(\mathrm{p}<0.05)$

The overall mean total cholesterol level was numerically lowest in untreated anestrus cows but did not differ significantly among different groups (table. 3 ). The findings are comparable with many previous reports [13, 18, 29] who recorded lower cholesterol concentration in anestrus cows. Like present study, nonsignificant difference in total cholesterol level was recorded by Dhami et al., [32] in conceived and nonconceived cows $(136.72 \pm 1.48$ vs $120.46 \pm 3.05 \mathrm{mg} / \mathrm{dl})$. Current findings are supported by Henerick et al. [35] who opined that the highest adrenal cholesterol values occur at estrus when females are under estrogen dominance eventually facing a decline later when progesterone phase sets in. This is again supported by present lower overall pooled value of cholesterol in conceived (progesterone dominance) than those of nonconceived cows.

\section{Effect of Hormone Therapy on Plasma Minerals Profile}

The serum calcium level did not vary significantly among groups (table. 3). Like present findings many previous reports mentioned nonsignificantly or significantly lower calcium level in anestrus cows as compared to values at induced estrus or cyclic cows [4, 13, 14, 26, 28, 29, 30, 36, 37], the available reports suggest that lower calcium level might be a cause of anestrus. Furthermore, in present study the calcium level was higher in conceived cows but did not differ significantly as compared to non-conceived contemporaries, conversely, Dhami et al., [32] reported nonsignificantly lower calcium level $(9.52 \pm 0.14$ vs $8.85 \pm 0.11 \mathrm{mg} / \mathrm{dl}$ ) in conceived than non-conceived ovsynch treated cows. Calcium primarily have indirect effect on reproduction [38] (hypocalcemia predispose 
the cows for parturient paresis) and sensitizes the tubular genitalia for action of hormone. Moreover, Capen and Rosol [39] opined that estrosgen increase intestinal calcium absorption. Calcium when severely deficient affect reproductive function adversely [40] moreover, calcium, calcium phosphorus ratio, and balance of calcium with vitamin D also linked to altered reproductive performance [41].

The mean phosphorus level did not differ significantly in different groups but the value was lowest in untreated anestrus cows (table. 3). Present findings suggest that as the animal approached towards cyclicity the phosphorus level was improved. Similar patterns documented in many previous reports [13, 26, 28, 29, 30]. Furthermore, Dhami et al. [32] observed nonsignificant difference among conceived and nonconceived cows using ovsynch protocols in crossbred cows. Blood level below $4 \mathrm{mg} / \mathrm{dl}$ usually indicate phosphorus deficiency [33, 42], normal values being 4 to $8 \mathrm{mg} / \mathrm{dl}$. Phosphorus is the mineral most frequently associated with reporoductive abnormalities in cattle [38], some scientists [43, 44] suggest that phosphorus deficiency causes infertility (anestrus, subestrus, irregular cycle, and low conception rates) while others [45] found no evidence of hypophosphataemia associated infertility. Thus, there is conflicting opinion of several scientists about hypophosphataemia as a cause of infertility [42].

The magnesium level was lowest in untreated anestrus cows as compared to treated cows, though the difference was nonsignificant (table. 3). Furthermore, the value was numerically higher in conceived cows than non-conceived one. Magnesium $(\mathrm{Mg})$ requirement is more at time of occurrence of high energy demand, as association of $\mathrm{Mg}$ is well known as a co-factor in all ATP requiring enzymatic processes in general metabolism.

Table-4: Overall mean ( \pm SE) blood micromineral status $(\mathrm{ppm})$ in different treatment groups and conceiving and non-conceiving cows

\begin{tabular}{|l|l|l|l|l|l|l|}
\hline Therapy/status & .n & Zinc & Iron & Copper & Cobalt & Manganese \\
\hline GnRH/true anestrus & 13 & $1.13 \pm 0.08$ & $2.94 \pm 0.14$ & $0.66 \pm 0.03$ & $0.18 \pm 0.02$ & $0.09 \pm 0.01$ \\
\hline PGF $_{2 \alpha}$ /subestrus & 23 & $0.72 \pm 0.04$ & $3.19 \pm 0.14$ & $0.63 \pm 0.03$ & $0.13 \pm 0.01$ & $0.08 \pm 0.01$ \\
\hline Control/untreated & 8 & $0.88 \pm 0.04$ & $2.63 \pm 0.12$ & $0.45 \pm 0.02$ & $0.13 \pm 0.01$ & $0.06 \pm 0.01$ \\
\hline Overall & 44 & $1.04 \pm 0.07$ & $3.06 \pm 0.09$ & $0.64 \pm 0.02$ & $0.14 \pm 0.01$ & $0.08 \pm 0.01$ \\
\hline Conceived & 25 & $1.05 \pm 0.12$ & $3.02 \pm 0.10$ & $0.65 \pm 0.03$ & $0.13 \pm 0.01$ & $0.06 \pm 0.01$ \\
\hline Non-conceived & 19 & $1.03 \pm 0.06$ & $3.09 \pm 0.14$ & $0.63 \pm 0.02$ & $0.15 \pm 0.01$ & $0.09 \pm 0.01$ \\
\hline
\end{tabular}

Means bearing different superscripts within column differ significantly $(\mathrm{p}<0.05)$

The overall pooled values of trace minerals (Zinc, iron, copper, cobalt and manganese) was neither differed significantly among anestrus, subestrus and control cows nor among conceived and non-conceived cows (table. 4). The iron, copper and manganese were lower in untreated anestrus cows than those of treated contemporaries. The serum trace minerals in our study are in close conformity with findings of Desai et al., [46]. Low iron level may be attributed to low tissue oxygenation of uterus which in turn results in impaired nutrition to the uterus [47], furthermore, copper plays important role in formation of hemoglobin, which is oxygen carrying pigment of the blood. Radostits et al., [48] opined that reproductive function of male and females are most sensitive to manganese deficiency. Present findings of lower iron and copper concentrations are consistent with observations of Vadnere and Singh [49] who reported significantly lower iron and copper level in anestrus cows than those of cyclic cows.

\section{CONCLUSION}

In conclusion, anestrus and subestrus conditions in crossbred cows can be effectively managed with aforesaid therapeutic regimes. Assessment of blood biochemical profile is important for better understanding of clinical syndrome of anestrus.

\section{ACKNOWLEDGEMENT}

We thank Dean of the faculty for facility provided and secretaries of village co-operative societies, including animal owner for the co-operation extended for this work. The financial support received from Research Scientist \& Head, RBRU, AAU, Anand through their DBT project is also gratefully acknowledged.

\section{REFERENCES}

1. Butani, M.G, Kumar R., Dhami, A.J., Kavani, F.S. and Killedar, A. (2008). Incidence of major infertility problems in crossbred cows and buffaloes under field conditions. Indian J. Field Vets, 4(2): 1-4.

2. Ashoo, Verma, H.C., Singh, R.K., Kumar, R., Ramakant, and Diwakar, R.P. (2020). Incidence of Reproductive Disorders in Cattle and Buffalo under Field Conditions in Eastern Plain Zone of Uttar Pradesh. Indian J, Vet Sci. Biotech., 16(1):6668.

3. Kumar, J., Srivastava, S., and Kumar, R. (2020). Effect of Herbal, Homeopathic and Hormonal Drug on Hematology, Ovarian Cyclicity and Conception Rate in Postpartum Anoestrus Cows. Ind J Vet Sci and Biotech, 16(1):17-21. 
4. Dhami, A.J., Patel, J.A., Hadiya, K.K., Parmar, S.C. and Chaudhary, D.V. (2019). Nutritional infertility and ameliorative measures in dairy animals of middle Gujarat. Indian J, Vet Sci. Biotech., 14(3): 05-09.

5. Bhatnagar, P.C., Chaudhary, J.L., Bhardwaj, B., Shakhar, C., Gupta, L. and Sharma, D.K. (2020). Effect of different hormonal protocols and nutrient supplementation on reproductive performance of cattle under different field conditions. International Journal of Current Microbiology, 9(1): 15111522.

6. Kubasic, N.P., Hallauer, G.D. and Brodows, R.G. (1984). Clinical Chemistry, 30(2): 284-286.

7. Snedecor, G.W., \& Cochran, W.G. (1994). Statistical Methods. 8th edn. The Iowa State University Press, Ames, Iowa, USA.

8. Karmakar, P.C., Das, P.K., and Bhattacharya, P.K. (2012). An approach to settle the true anestrus cases using GnRH and minerals in crossbred heifers. Proceeding of the XXVIII Anuual Convention and National Symposium of ISSAR on 'Addressing animal reproductive stresses through biotechnological tools'. C.V.Sc., A.A.U., Khanapara, Guwahati. 21-23 November 2012:69.

9. EL-Shahat, K.H., \& Badr, A. (2011). Comparative study on different medicaments on postpartum anestrus dairy cows. Journal of Applied Biological Sciences, 5(3): 59-63.

10. Kamal, M.M., Rahman, M.M., Momont, H.W. and Shamsuddin, M. (2012). Underlying disoreder of postpartum anestrus and their effectiveness of their treatments in crossbred dairy cows. Asian Journal of Animal sciences, 6(3): 132-139.

11. Gupta, V.S., Gupta, B., \& Patidar, A. (2012). Efficacy comparison between Cloprostenol and $\mathrm{GnRH}$ analogue on anestrus cows- a field studies. DHR international journal of biomedical and Life Sciences (DHR-IJBLS), 3(1): 47-50.

12. Islam, M.R., Juyena, N.S., Bhuiyan, M.M.U., Rahman, M.M., and Ferdousy, R.N. (2013). Treatment outcomes in postpartum anestrus cows guided by transrectal ultrasonography. Progressive Agriculture, 24: 93-100.

13. Soni, Y.K., Kumar, S., Saha, S., Pande, M., Prasad, R., Singh, J.K., Verma, S.K. and Bansal, B.K. (2018). Oestrus induction and fertility response in anoestrus Frieswal heifers subjected to various treatments. International Journal of Livestock Research, 8(2): 146-152.

14. Dutta, L.J., Nath, K.C., Deka, B.C., Bhuyan, D., Borah, P., Saikia, G.K., Bora, D.P., Deka, R., Acharya, C. and Bharali, D. (2019). Therapeutic management of true anestrud crossbred cows through nutritional and hormonal intervention. Entomology and Zoology Studies, 7(3): 09-12.

15. Ratnaparkhi, A.R. Deshmukh, S.G. Birade, H.S. Kale, V.B. Harkal, S.B. and Jadhao, A.D. (2020). Comparative Efficacy of Synchronization Protocols for Improving Fertility in Postpartum Crossbred Dairy Cows. Haryana Vet, 59(SI): 23-26.

16. El-Desouky, A.M., \& Hussein, M.S. (2015). Therapeutic effect of single over-dose of PGF $2 \alpha$ on typical postpartum anestrus in dairy cows. Benha Veterinary Medical Journal, 28(1): 1-7.

17. Daily, R.A., Inskeep, E.K., Washburn, S.P. and Price, J.C. (1983). Use of prostaglandin $F_{2 \alpha}$ or Gonadotropin releasing hormone in treating problem breeding cows. J. Dairy Sci., 66: 17211727.

18. Weems, C.W., Weems, Y.S., \& Randel, R.D. (2006). Prostaglandins and reproduction in female farm animals. The Veterinary Journal, 171: 206228.

19. Randel, R.D., Lammoglia, M.A., Lewis, A.W., Neuendorff, D.A. and Guthrie, M.J. (1996). Exogenous $\mathrm{PGF}_{2 \alpha}$ enhanced GnRH induced $\mathrm{LH}$ release in postpartum cows. Theriogenology, 45: 643-654.

20. Murdoch, W.J., McCormick, R.J., (1993). Mechanisms and physiological implications of leukocyte chemoattraction into periovulatory ovine follicles. Journal of Reproduction and Fertility, 97: 375-380.

21. Pfeifer, L.F.M., Rodrigues, W.B., da Silva, K.C., Anache, N.A., Castro, N.A., Castilho, E.M., and Nogueira, N. (2018). Different protocols using $\mathrm{PGF}_{2} \alpha$ as ovulation inducer in Nelore cows subjected to estradiol-progesterone timed AI based protocols. Theriogenology. 120: 56-60.

22. Pfeifer L.F.M., Leonardi, C.E., Castro, N.A., Viana, J.H., Siqueira, L.G., Castilho, E.M. (2014).The use of PGF2alpha as ovulatory stimulus for timed artificial insemination in cattle. Theriogenology, 81: 689-695.

23. Pfeifer, L.F.M., Siqueira, L.G.B., Arashiro, E.K.N., Castro, N.A. and Viana, J.H.M. (2016). Prostaglandin $F_{2} \alpha$ or estradiol benzoate to induce ovulation in timed artificially inseminated dairy cows. Pesqui Agropecu!aria Bras, 51:738-744.

24. Dawson, F.L. (1975). Accuracy of rectal palpation in the diagnosis of ovarian function in the cow. Vet. Record., 96(10): 218-220.

25. Hanzen, Ch., Pieterse, M., Scenczi, O. and Drost, M. (2000). Relative accuracy of the identification of ovarian structures in the cow by ultrasonography and palpation per rectum. The Veterinary Journal, 159: 161-170.

26. Virmani, M., Malik, R.K., Singh, P., \& Dalal, S.S. (2011). Studies on blood biochemical profile with the treatment of acyclicity in post-partum anestrus Sahiwal cows. Haryana Vet., 50: 77-79.

27. Krupakaran, P. (2013). Serum biochemical profile og Jersey crossbred heifers. International Journal of food, Agriculture and Veterinary Science, 3(1), 9-11.

28. Ray, K., Biswas, P., Banerjee, U., Basu, S. and Sarkar, B. (2016). Supplementation of herbal oestrus inducer and mineral mixture combinations 
on haemato-biochemical profile of crossbred cows. Indian J.Anim. Health, 55(2): 141-148.

29. Kumar, J., Srivastava, S., \& Kumar, R. (2018). Studies on Janova, Sepia and GnRH-PG-GnRH regimen on induction of cyclicity in postpartum anoestrus cows. Bull. Env. Pharmacol. Life Sci., 7(2): 22-28.

30. Mangrole, V., Bhardwaj, A., Aich, R., Shivhare, M., Kumar, S. and Mandhwani, R. (2019). Comparative studies on haemato-biochemical parameters of anoestrus crossbred cows treated with different therapeutic regimen. International Journal of Livestock Research, 9(1): 300-308.

31. Mondal, A.K., Begum, S., Islam, S., Hasan, M.M.I., Rahman, M.M. and Howlader, M.M.R. (2019). Assessment of hematobiochemical profile of postpartum crossbred anestrus cows compared with the cyclic cows. Biomed. J. Sci. and Tech. Res. 17(3): 1203-1207.

32. Dhami, A.J., Nakrani, B.B., Hadiya, K.K., Patel, J.A., \& Shah, R.G. (2015). Comparative efficacy of different estrus synchronization protocols on estrus induction response, and plasma progesterone and biochemical profile in crossbred anestrus cows. Vet. World, 8: 1310-1316.

33. Roberts, S.J. (1986). Veterinary Obstetrics and Genital Diseases. $3^{\text {rd }}$ Ed. N.Y. Ithaka.

34. Pandey, N.K.J., Gupta, H.P., Prasad, S., \& Sheetal, S.K. (2015). Altewration in blood biochemical profile in pregnant and non-pregnant crossbred cows following exogenous supplementation of GnRH, HCG, and progesterone releasing intravaginal; devices. Indian Journal of Animal Reproduction, 36(2): 33-38.

35. Henerick, D.M., Dickey, I.A. and Hill, J.R. (1971). Plasma oestrogen and progesterone levels in cows prior to and during oestrus. Endocrinology, 89:1350

36. Agrawal. J.K., Saxena, A., \& Singh, V. (2015). Study on metabolic profile of repeat breeder, postpartum anestrus and normal cyclic Sahiwal cows. Indian J. Anim. Reprod., 36(1): 53-55.

37. Satapathy, D., Mishra, S.K., Swain, R.K., Sethy, K., Baril, S., Sahoo, J.K., \& Boitai, S.S. (2018). Incidence of reproductive problems and blood mineral status of crossbred cattle in Kakatpur block of Odisha, India. Int. J. Curr. Microbiol. App. Sci., special Issue 7: 471-480.

38. Gerloff, B.J., \& Morrow, D.A. (1986). Effect of nutrition on reproduction on Reproduction in Dairy
Cattle. In D.A. Morrow (Ed.). Current therapy in theriogenology 2, Diagnosis, treatment and prevention of reproductive diseases $\left(2^{\text {nd }}\right.$ ed. $p$. 310-320). W.B. Sounders Company, USA.

39. Capen, C.C., \& Rosol, T.J. (2003). The calcium regulating hormones: Parathyroid hormone, Calcitonin, and Cholecalciferol. In: M.H. Pineda and M. P. Doole. (2003): McDonald's Veterinary Endocrinology and Reproduction (5 ${ }^{\text {th }}$ ed., pp. 71140). A Blackwell Publishing Company, USA.

40. Youngquist, R.S., \& Threlfall, W.R. (1997). Current Therapy in Large Animal Theriogenology, 1 st edition, W.B. Saunders Company, USA

41. Spain, J.N., Lucy, M.C., \& Hardin, D.K. (2012). Effect of Nutrition on Reproduction in Dairy Cattle. In R.S.Youngquist and W. R. Threlfall (Ed). Current Therapy in Large Animal Theriogenology $\left(2^{\text {nd }}\right.$ ed., pp. 442-450). W.B. Saunders Company, USA.

42. Noakes, D.E., Parkinson, T.J., \& England, G.C.W. (2019). Veterinary Reproduction and Obstetrics. (10 $10^{\text {th }}$ Ed.) Saunders Ltd.

43. Morrow, D. A. (1969). Phosphorus deficiency and infertility in dairy heifers. J. Am. Vet.Med. Assoc. 154: 761.

44. Morris, R.S. (1976). Diagnosis of infertility in large dairy herds. Sydney: Refresher course for veterinarians. Proc no 28.

45. Carstairs, J.A., Morrow, D.A., and Emery, R.S. (1980). Postpartum reproductive function of dairy cows as influenced by energy and phosphorus status. J. Anim. Sci. 51: 1122-1130

46. Desai, H.B., Pande, M.B., Desai, M.C., \& Shukla, P.C. (1979). Haematological and chemical status of blood of Dangi cattle. Indian J. Anim. Res., 13:4346.

47. Reddy, L.Y.S., \& Reddy, S.M. (1988). Blood serum levels of iron in fertile and infertile cows. Indian J. Dairy Sci., 41(1): 18-20.

48. Radostits, O.M., Gay, C.C., Hinchcliff, K.W., \& Constable, P.D. (2007). Veterinary Medicine. A text Book of the disease of Cattle, Horses, Sheep, Pigs and Goats. $10^{\text {th }}$ ed. Saunders, Philadelphia, USA.

49. Vadnere, S.V., \& Singh, S. (1989). Blood plasma level of iodine, calcium, inorganic phosphorus, copper and iron in postpartum anoestrus crossbred cows. Indian J. Anim. Reprod., 10(2): 145-146. 